\title{
ChemComm
}

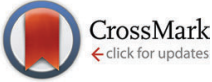

Cite this: Chem. Commun., 2016, 52,6785

Received 16th March 2016 , Accepted 12th April 2016

DOI: $10.1039 / c 6 c c 02316 a$

www.rsc.org/chemcomm

\section{Bis-phosphine allene ligand: coordination chemistry and preliminary applications in catalysis $\uparrow$}

\author{
Avassaya Vanitcha, ${ }^{a}$ Cecilia Damelincourt, ${ }^{a}$ Geoffrey Gontard, ${ }^{a}$ Nicolas Vanthuyne, \\ Virginie Mouriès-Mansuy ${ }^{\star a}$ and Louis Fensterbank ${ }^{\star a}$
}

\begin{abstract}
A 1,3-bis-diphenylphosphine allene can give rise to new coordination complexes with palladium, platinum and gold metals. These complexes were fully characterized by NMR, HRMS and X-ray diffraction analysis. For gold( $(1)$, the corresponding dinuclear complex has been used in a series of diagnostic catalytic reactions and gave promising preliminary results in asymmetric catalysis.
\end{abstract}

Coordination chemistry has been at the center of chemists' preoccupations since the pioneering works of Christian Wilhem Blomstrand, Sophus Mads Jorgensen and Alfred Werner in the 19th century. This very fundamental and intense domain of investigation has continuously irrigated several fields of applications such as catalysis, material sciences, and supramolecular and medicinal chemistry. ${ }^{1}$ Based on the interaction between a ligand and a metal center, the game of combining both components appears unlimited and the number of existing coordination adducts is still restricted, leaving a vast unexplored chemical space. Nevertheless, a rational design is desirable to guarantee the preparation of materials with optimized properties. This approach generally requires one to start from elementary building blocks (ligand or metal) with particular attributes.

Thus, thanks to its unique stereoelectronic features, an allene scaffold bearing a Lewis base and possibly conveying some chiral information sites appeared to us as a valuable keystone (Scheme 1). ${ }^{2}$ As a further incentive, there has been, to the best of our knowledge, a very limited number of allene-derived ligands involved in metallic coordination complexes. Krause reported the formation of silver and copper complexes from allene-containing bipyridine ligands, but no catalytic activity was reported. ${ }^{3}$ Chiral diphosphine oxide allenes were first used as organocatalysts by Ready who described

\footnotetext{
${ }^{a}$ Sorbonne Universités UPMC Univ Paris 06, CNRS, UMR 8232, Institut Parisien de Chimie Moléculaire, 4 place Jussieu, C.229, F-75005 Paris, France

${ }^{b}$ Aix-Marseille Université, Centrale Marseille, CNRS, iSm2 UMR 7313, 13397, Marseille, France

$\dagger$ Dedicated to Antonio Echavarren.

\# Electronic supplementary information (ESI) available. CCDC 1448365 and 1448367-1448371. For ESI and crystallographic data in CIF or other electronic format see DOI: 10.1039/c6cc02316a
}

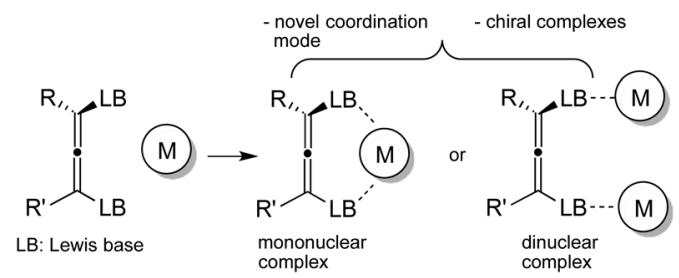

Scheme 1 New prospects in coordination chemistry with allene ligands.

the highly enantioselective formation of chlorohydrins from meso-epoxides with $\mathrm{SiCl}_{4}{ }^{4}$ Later, the same group devised chiral allene-containing bisphosphines that, when coordinated to $\mathrm{Rh}(\mathrm{I})$, were able to promote the asymmetric addition of arylboronic acids to $\alpha$-keto esters with high enantioselectivity. ${ }^{5}$

In line with this strategy, our attention was drawn to the bis-phosphine 1,3-bis(diphenylphosphino)-1,3-diphenylallene (1) featuring direct attachment of the phosphorus moieties on the allene scaffold, which has been so far very rarely encountered. ${ }^{6}$ The Schmidbaur group previously described the synthesis of $\mathbf{1}^{7}$ Following their procedure, we obtained $\mathbf{1}$ in a consistent yield of $48 \%$ (Scheme 2).

We then studied the unexplored coordination properties of 1 and focused on the possibility of obtaining mononuclear palladium(II) and platinum(II) complexes. Thus, heating at $80{ }^{\circ} \mathrm{C}$ for $4 \mathrm{~h}$, a 1:1 mixture of bis(acetonitrile)dichloropalladium and 1 in toluene afforded the coordination complex 3 ( $84 \%$ yield) that was isolated as an orange solid after precipitation in cold ether. ${ }^{31} \mathrm{P}$ NMR showed a singlet peak resonance at $\delta_{\mathrm{P}}=128.3 \mathrm{ppm}$, very downfield compared to the starting allene $\mathbf{1}\left(\delta_{\mathrm{P}}=33.2 \mathrm{ppm}\right)$ and the ${ }^{13} \mathrm{C}$ peak of the central allene carbon was observed as a triplet peak $\left(\mathrm{t},{ }^{2} J_{\mathrm{CP}}=3.8 \mathrm{~Hz}\right)$ at $193.3 \mathrm{ppm}\left(\delta=209.9 \mathrm{ppm}, \mathrm{d},{ }^{2} J_{\mathrm{CP}}=3.5 \mathrm{~Hz}\right.$ for $\left.\mathbf{1}\right)$.

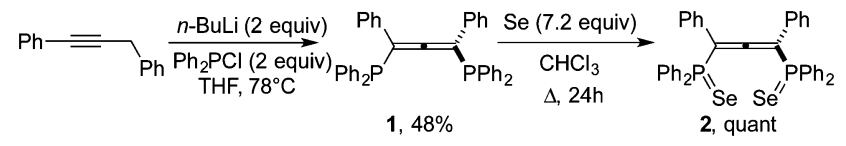

Scheme 2 Allene bisphosphine 1 and its bis-seleno derivative 2 . 


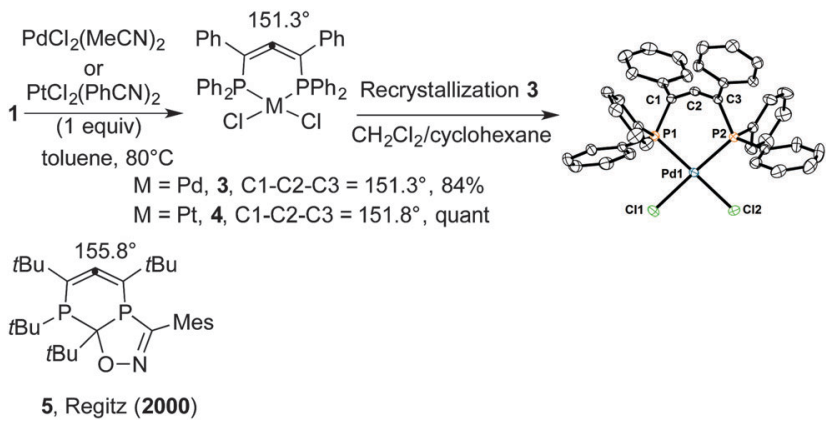

Scheme $3 \mathrm{Pd}$ and Pt mononuclear complexes with ligand 1.

An initial crystallization attempt of the bis-P-coordinated Pd allene complex 3 in $\mathrm{MeOH}$ provided suitable material for a single-crystal X-ray diffraction (XRD) analysis. Interestingly, the latter showed a co-crystallized mixture of $\mathrm{MeOH}$ and $\mathrm{HCl}$ adducts on 3 (see ESI ). While these findings strongly suggested the formation of the Pd-allene complex 3, its structure was fully confirmed after XRD analysis of crystals grown in a $\mathrm{CH}_{2} \mathrm{Cl}_{2}$ / cyclohexane mixture (Scheme 3$).{ }^{8}$ A square planar coordination was observed. More striking was the severely bent character of the allene moiety, exhibiting a $\mathrm{C}=\mathrm{C}=\mathrm{C}$ bond angle of $151.2(2)^{\circ}$. The C1-C2 and C2-C3 bond lengths of respectively 1.303(3) and 1.315(3) A lie in the typical range observed for cumulenes. ${ }^{9}$

Similarly, platinum complex $\mathbf{4}$ was formed quantitatively. ${ }^{31} \mathrm{P}$ NMR shows a central resonance at $\delta_{\mathrm{P}}=98.7 \mathrm{ppm}$ with two small satellite peaks due to ${ }^{195} \mathrm{Pt}\left({ }^{1} J^{31} \mathrm{P}-195 \mathrm{Pt}=4371 \mathrm{~Hz}\right)$. Here also, the ${ }^{13} \mathrm{C}$ peak of the allene central carbon is more shielded $\left(\delta=198.9 \mathrm{ppm},{ }^{2} J_{\mathrm{CP}}=5.1 \mathrm{~Hz}\right)$. The XRD analysis ${ }^{8}$ confirmed the structure and also showed a square planar coordination with a similar $\mathrm{C}=\mathrm{C}=\mathrm{C}$ bent angle of $151.8(4)^{\circ}$ (see $\mathrm{ESI}+$ ).

A few bent allenes have previously been reported ${ }^{10}$ though there has been some controversy in assigning an allenic character to some of them. ${ }^{11}$ The most structurally related example to 3 or 4 corresponds to cyclic allene 5, previously isolated by Regitz and exhibiting a $\mathrm{C}=\mathrm{C}=\mathrm{C}$ angle of $155.8^{\circ} .^{6 c}$ While palladium complex $\mathbf{3}$ appears quite stable, platinum complex $\mathbf{4}$ decomposed in a few days upon standing on the bench at room temperature.

These preliminary findings validated the coordination ability of allene 1 so we looked at the possible formation of gold complexes in connection with our interest in gold catalysis. ${ }^{12,13}$ Our initial attempt focused on the formation of a tricoordinate mononuclear complex as more and more examples ${ }^{14}$ of this coordination mode have been reported and shown intriguing properties. $^{15}$ Interestingly, when mixing 1.1 equiv. of 1 with 1 equiv. of $\mathrm{Me}_{2} \mathrm{SAuCl}$ in $\mathrm{CH}_{2} \mathrm{Cl}_{2}$ at $-20{ }^{\circ} \mathrm{C}$, a new species ( $\delta_{\mathrm{P}}=12.5 \mathrm{ppm}$, broad peak) was selectively formed. The XRD analysis revealed the polymeric gold complex $6 .^{16,17}$ While the properties of these macromolecular complexes will be studied, we turned our attention to dinuclear complexes.

Thus, treatment of 1 with 2 equiv. of $\mathrm{Me}_{2} \mathrm{SAuCl}$ in $\mathrm{CH}_{2} \mathrm{Cl}_{2}$ provided quantitatively the chiral gold(I) complex rac-7. The latter proved to be quite stable to air and moisture. Its structure was also confirmed by XRD studies (Scheme 4). ${ }^{17}$ Despite the known carbophilicity of gold(I) salts, ${ }^{18}$ coordination took place
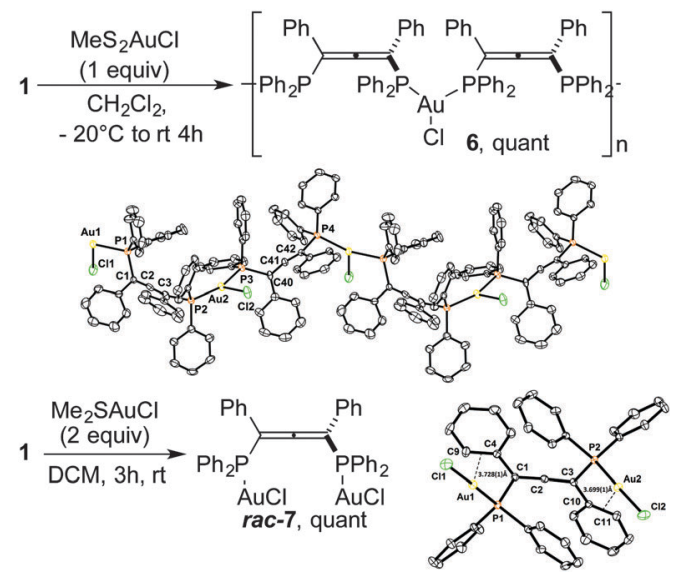

Scheme 4 Mononuclear and dinuclear gold(ı) complexes.

exclusively on the phosphine moieties, leaving the allene unaltered. The two $\mathrm{Au}$ atoms lie in opposite direction, with an $\mathrm{Au}-\mathrm{Au}$ distance of 6.498(1) A precluding any aurophilic interaction. ${ }^{19}$ The distance between the Au atom and the phenyl group of the allene moiety is, on average, 3.71(2) ^ suggesting no $\eta^{1}$ or $\eta^{2}$ interaction as described for the JohnPhos gold(I) chloride complex and congeners. $^{20}$

The evaluation of the electronic properties of allene $\mathbf{1}$ was achieved by measuring the magnitude of ${ }^{1} J_{\mathrm{P}-\mathrm{Se}}$ for the ${ }^{77} \mathrm{Se}$ isotopomer ${ }^{21}$ of the corresponding bis-selenide derivative 2 (Scheme 2). With a ${ }^{1} J_{\mathrm{P}-\mathrm{Se}}$ value of $754 \mathrm{~Hz}$, allene 1 exhibits an intermediate $\sigma$-donor ability, lower than that of $\mathrm{PPh}_{3}\left({ }^{1} J_{\mathrm{P}-\mathrm{Se}}=\right.$ $728 \mathrm{~Hz})$ but much higher than that of $\mathrm{P}(\mathrm{PhO})_{3}\left({ }^{1} J_{\mathrm{P}-\mathrm{Se}}=1027 \mathrm{~Hz}\right) .{ }^{22}$

We then evaluated the catalytic activity of gold complex rac-7 using the prototypical $N$-tethered 1,6-enyne precursor 8a. The reaction was carried out in $\mathrm{CH}_{2} \mathrm{Cl}_{2}$ with a catalytic $1: 1$ mixture of rac-7 (3 mol\%) and $\mathrm{AgSbF}_{6}$ to afford diene 9a in $74 \%$ yield. When 1,6-enyne $\mathbf{8 b}$ was treated under the same conditions, only starting material was recovered even under refluxing conditions. An additional $3 \mathrm{~mol} \%$ of silver salt gave the expected product $9 \mathbf{b}$ in $52 \%$ yield. It is noteworthy that when 2 equiv. of $\mathrm{AgSbF}_{6}(6 \mathrm{~mol} \%)$ were introduced right from the start of the reaction, compound $\mathbf{9 a}$ was obtained in similar yield as with $3 \mathrm{~mol} \%$ but we observed a better yield (85\%) for compound $\mathbf{9 b}$ (Scheme 5).

As previously reported in the literature ${ }^{23}$ and by us, ${ }^{24}$ we suspected the detrimental formation of a chloride-bridged digold complex. The latter was detected by ESI MS at $20 \mathrm{~V}$ (see ESI $\ddagger$ ) from an equimolar mixture of 1 and $\mathrm{AgSbF}_{6}$ in $\mathrm{CH}_{2} \mathrm{Cl}_{2}$, as attested by the presence of a peak at $m / z 989\left(\mathrm{C}_{39} \mathrm{H}_{30} \mathrm{Au}_{2} \mathrm{ClP}_{2}{ }^{+}\right)$. This complex would be cleaved by more coordinating substrates like $8 \mathbf{a}$ or by

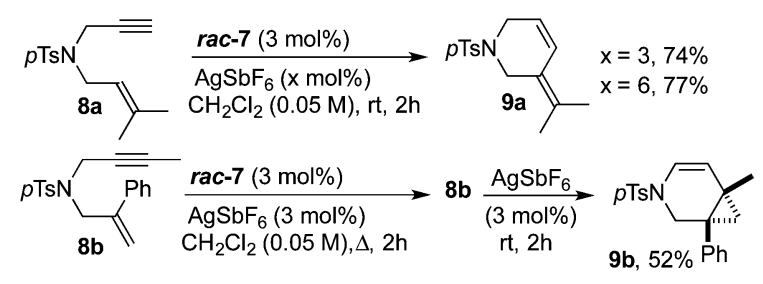

Scheme 5 Preliminary catalytic testing. 


\section{Alkyne activation}
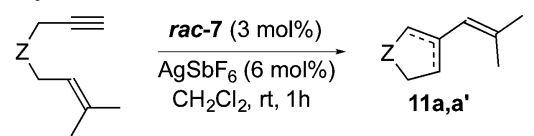

$\mathrm{Z}=\mathrm{C}\left(\mathrm{CO}_{2} \mathrm{Me}\right)_{2}, 10$ 11a:11a' $=2: 1,70 \%$

$10 \frac{\text { rac-7 }(3 \mathrm{~mol} \%)}{\mathrm{AgSbF}_{6}(6 \mathrm{~mol} \%)}$ $\mathrm{MeOH}, \mathrm{rt}, 24 \mathrm{~h}$

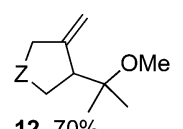

$12,70 \%$

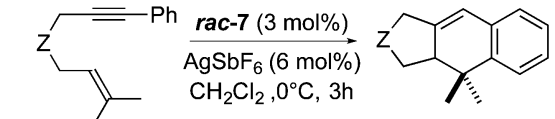

$\mathrm{Z}=\mathrm{C}\left(\mathrm{CO}_{2} \mathrm{Me}\right)_{2}, 13$ $\mathrm{CH}_{2} \mathrm{Cl}_{2}, 0^{\circ} \mathrm{C}, 3 \mathrm{~h}$<smiles>C#CC(C)(C)OC(=O)OCC=C</smiles>

15

Allene activation<smiles>[Z]C/C=C\C=C(C)C(C)C</smiles>

14, quant

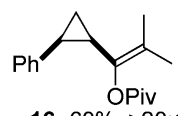

$16,60 \%,>20:$

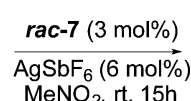
$\mathrm{MeNO}_{2}$, it, $15 \mathrm{~h}$

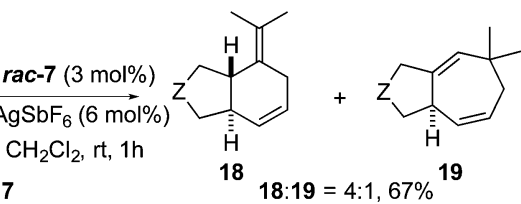

Scheme 6 Scope of catalysis with rac-7.

the addition of an excess of silver salt yielding a dicationic gold catalytic species.

Following the previously defined reaction conditions, we extended the investigation of the electrophilic catalytic properties of rac-7 by examining the reactivity of several representative polyunsaturated substrates. Thus, enyne $\mathbf{1 0}$ provided regioselectively cyclopentadienic dienes $11 a, \mathbf{a}^{25}$ in $70 \%$ yield with no cyclohexadienic product. ${ }^{13 c}$ Running the same reaction in methanol as solvent did not affect the catalytic activity and gave smoothly methoxycyclization adduct $\mathbf{1 2}$ as a single regioisomer. ${ }^{25}$ The quantitative conversion of enyne 13 into tricyclic derivative 14 confirmed the robustness of this catalytic system. ${ }^{26}$

Intermolecular gold-catalyzed additions offer interesting synthetic opportunities. We evaluated the intermolecular cyclopropanation reaction between propargyl pivalate $\mathbf{1 5}$ and styrene and were pleased to obtain cyclopropane adduct 16 in $60 \%$ yield and with improved diastereoselectivity $(>20: 1)$ in favor of the cis-isomer than previously reported $(>6: 1) .{ }^{27}$ The cycloisomerization of allenediene $\mathbf{1 7}$ served as a very informative probe. It showed that the chemoselective activation of an allene was possible with our allene-based catalytic system since a $4: 1$ mixture of [4+2] and [4+3] cycloadducts 18 and 19 was obtained in $67 \%$ yield. The major formation of 18 suggests a rather electron-depleted catalytic species, more electrophilic than with triphenylphosphine as ligand which gives a 2:1 ratio of 18 and $19 .^{28}$ This product distribution is thus consistent with our preliminary evaluation of the electronics with bis-seleno derivative 2 (Scheme 6).

We finally wished to look at the possibility of using the chirality of ligand 1 for asymmetric transformations. ${ }^{29}$ Although the number of optical resolutions of organometallic complexes
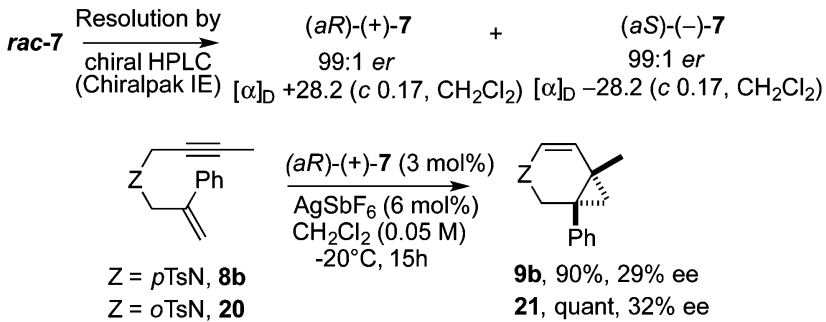

Scheme 7 Resolution and asymmetric catalysis.

by preparative HPLC remains limited, ${ }^{30}$ and to the best of our knowledge none with gold, ${ }^{31}$ we tried this method on the gold chloride complex rac-7. Gratifyingly, the enantiomers of complex rac-7 were nicely separated by analytical chiral chromatography on a Chiralpak IE column. Each enantiomer was obtained with high ee of $98 \%$ and their absolute configuration determined by anomalous XRD. ${ }^{32}$ We then evaluated the catalytic activity of $(a R)-(+)-7$ for the asymmetric cycloisomerisation of 1,6-enynes $\mathbf{8 b}$ and 20. The expected azabicyclo[4.1.0]heptenes $\mathbf{9 b}$ and 21 were obtained in good yields and with promising ee values of 29 and $32 \%$, respectively (Scheme 7).

This journey in the coordination of bis-phosphine allene $\mathbf{1}$ with palladium, platinum and gold salts has allowed the formation of highly novel and original coordination complexes. Physico-chemical properties of these complexes will be pursued. Focusing on gold(I) salts, we could generate a new type of chiral dinuclear gold precatalyst. The precatalyst rac-7 in the presence of a silver salt proved to be very active and robust in a series of prototypical gold-catalyzed reactions. Investigation of the electronic properties suggests a moderately electrophilic gold complex which was corroborated by catalytic results. Preliminary testing of the corresponding optically pure complex obtained by preparative chiral HPLC gave promising hits for asymmetric catalysis. It is anticipated that fine electronic and steric tuning of the allene bis-phosphine ligand by appropriate substitution should boost the catalytic properties.

\section{Notes and references}

1 (a) Comprehensive Coordination Chemistry II, ed. J. A. McCleverty and T. J. Meyer, Elsevier, Boston, 2004; (b) Comprehensive Organometallic Chemistry, ed. R. H. Crabtree and D. M. P. Mingos, Elsevier, 3rd edn, 2007; (c) Bioorganometallic Chemistry: Applications in Drug Discovery, Biocatalysis and Imaging, ed. G. Jaouen and M. Salmain, Wiley, 2015; (d) M. Han, D. M. Engelhard and G. H. Clever, Chem. Soc. Rev., 2014, 43, 1848; (e) M. M. J. Smulders, I. A. Riddell, C. Browne and J. R. Nitschke, Chem. Soc. Rev., 2013, 42, 1728; $(f)$ K. Harris, D. Fujita and M. Fujita, Chem. Commun., 2013, 49, 6703; $(g)$ T. R. Cook, Y. R. Zheng and P. J. Stang, Chem. Rev., 2013, 113, 734; $(h)$ D. L. Caulder and K. N. Raymond, Acc. Chem. Res., 1999, 32, 975; (i) C. G. Hartinger, N. Metzler-Nolte and P. J. Dyson, Organometallics, 2012, 31, 5677.

2 (a) Modern Allene Chemistry, ed. N. Krause and A. S. K. Hashmi, Wiley-VCH, Weinheim, 2004; (b) S. Yu and S. Ma, Angew. Chem., Int. Ed., 2012, 51, 3074.

3 S. Löhr, J. Averbeck, M. Schürmann and N. Krause, Eur. J. Inorg. Chem., 2008, 552.

4 X. Pu, X. Qi and J. M. Ready, J. Am. Chem. Soc., 2009, 131, 10364.

5 F. Cai, X. Pu, X. Qi, V. Lynch, A. Radha and J. M. Ready, J. Am. Chem. Soc., 2011, 133, 18066.

6 (a) H. Schmidbaur and T. Pollock, Angew. Chem., Int. Ed., 1986, 25, 348; (b) H. Schmidbaur, T. Pollock, G. Reber and G. Müller, 
Chem. Ber., 1987, 120, 1403; (c) M. A. Hofmann, U. Bergsträßer, G. J. Reiß, L. Nyulászi and M. Regitz, Angew. Chem., Int. Ed., 2000, 39, 1261; (d) G. Gangadhararao, R. N. P. Tulichula and C. K. Swamy, Chem. Commun., 2015, 51, 7168.

7 H. Schmidbaur, C. M. Frazão, G. Reber and G. Müller, Chem. Ber., 1989, 122, 259.

8 CCDC 1448365 (3) and 1448367 (4).

9 R. P. Johnson, Chem. Rev., 1989, 89, 1111.

10 (a) D. S. Patel and P. V. Bharatam, J. Org. Chem., 2011, 76, 2558; (b) E. Weber, W. Seichter, B. Hess, G. Will and H. J. Dasting, J. Phys. Org. Chem., 1995, 8, 94; $(c)$ see also in ref. 5: a Pt(allenyl monophosphine) complex showed a severely bent allene $(\mathrm{C}=\mathrm{C}=\mathrm{C}$ angle of $152^{\circ}$ ) due to a Pt-allene interaction.

11 (a) V. Lavallo, C. A. Dyker, B. Donnadieu and G. Bertrand, Angew. Chem., Int. Ed., 2009, 48, 1540; (b) M. Christl and B. Engels, Angew. Chem., Int. Ed., 2009, 48, 1538.

12 For recent reviews, see: (a) R. Dorel and A. M. Echavarren, Chem. Rev., 2015, 115, 9028; (b) M. Jia and M. Bandini, ACS Catal., 2015, 5, 1638; (c) D. Qian and J. Zhang, Chem. Soc. Rev., 2015, 44, 677; (d) See also a special Gold Catalysis issue of Accounts of Chemical Research: C. Friend and A. S. K. Hashmi, Gold Catalysis, Acc. Chem. Res., 2014, 47(3)(e) D. Pflästerer and A. S. K. Hashmi, Chem. Soc. Rev., 2016, 45, 1331.

13 (a) D. Leboeuf, A. Simonneau, C. Aubert, M. Malacria, V. Gandon and L. Fensterbank, Angew. Chem., Int. Ed., 2011, 50, 6868; (b) A. Simonneau, F. Jaroschik, D. Lesage, M. Karanik, R. Guillot, M. Malacria, J.-C. Tabet, J.-P. Goddard, L. Fensterbank, V. Gandon and Y. Gimbert, Chem. Sci., 2011, 2, 2417; (c) M. Guitet, P. Zhang, F. Marcelo, C. Tugny, J. Jimenez-Barbero, O. Buriez, C. Amatore, V. Mouriès-Mansuy, J.-P. Goddard, L. Fensterbank, Y. Zhang, S. Roland, M. Ménand and M. Sollogoub, Angew. Chem., Int. Ed., 2013, 52, 7213; (d) F. Nzulu, A. Bontemps, J. Robert, M. Barbazanges, L. Fensterbank, J.-P. Goddard, M. Malacria, C. Ollivier, M. Petit, J. Rieger and F. Stoffelbach, Macromolecules, 2014, 47, 6652; (e) A. Simonneau, Y. Harrak, L. Jeanne-Julien, G. Lemière, V. Mouriès-Mansuy, J.-P. Goddard, M. Malacria and L. Fensterbank, ChemCatChem, 2013, 5, 1096; $(f)$ L. Ferrand, N. Das Neves, M. Malacria, V. Mouriès-Mansuy, C. Ollivier and L. Fensterbank, J. Organomet. Chem., 2015, 795, 53; (g) A. Vanitcha, G. Gontard, N. Vanthuyne, E. Derat, V. Mouriès-Mansuy and L. Fensterbank, Adv. Synth. Catal., 2015, 357, 2213.

14 (a) O. Crespo, M. C. Gimeno, A. Laguna and P. G. Jones, J. Chem. Soc., Dalton Trans., 1992, 1601; (b) M. C. Gimeno and A. Laguna, Chem. Rev., 1997, 97, 512.

15 (a) For a review, see: M. Joost, A. Amgoune and D. Bourissou, Angew. Chem., Int. Ed., 2015, 54, 15022; (b) J. G. Guenther, S. Mallet-Ladeira, L. Estevez, K. Miqueu, A. Amgoune and D. Bourissou, J. Am. Chem. Soc., 2014, 136, 1778; (c) H. Yang and F. P. Gabbai, J. Am. Chem. Soc., 2015, 137, 13425.

16 For Au(I)-based polymeric chains, see: (a) S. H. Lim, M. L. Olmstead and A. L. Balch, J. Am. Chem. Soc., 2011, 133, 10229; (b) V. J. Catalano, M. A. Malwitz, S. H. Horner and J. Vasquez, Inorg. Chem., 2003, 42, 2141; (c) M. Streitberger, A. Schmied and E. Hey-Hawkins, Inorg. Chem., 2014, 53, 6794; (d) L.-T. Phang, T. S. A. Hor, Z.-Y. Zhou and T. C. W. Mak, J. Organomet. Chem., 1994, 469, 253; (e) C. Khin, A. S. K. Hashmi and F. Rominger, Eur. J. Inorg. Chem., 2010, 1063.

17 CCDC 1448368 (6) and 1448369 (rac-7).

18 For reviews on the coordination of gold salts onto allenes: (a) M. Malacria, L. Fensterbank and V. Gandon, Top. Curr. Chem., 2011, 302, 157; (b) E. Soriano and I. Fernandez, Chem. Soc. Rev., 2014, 43, 3041; (c) W. Yang and A. S. K. Hashmi, Chem. Soc. Rev., 2014, 43, 2941; For coordination complexes, see: (d) A. Fürstner, M. Alcarazo, R. Goddard and C. W. Lehmann, Angew. Chem., Int. Ed., 2008, 47, 3210; (e) T. J. Brown, A. Sugie, M. G. Leed and R. A. Widenhoefer, Chem. - Eur. J., 2012,
22, 6959; for the first description of gold-catalyzed additions to allenes, see: $(f)$ A. S. K. Hashmi, L. Schwarz, J.-H. Choi and T. M. Frost, Angew. Chem., Int. Ed., 2000, 39, 2285.

19 (a) H. Schmidbaur and A. Schier, Chem. Soc. Rev., 2012, 41, 370; (b) A. S. K. Hashmi, Acc. Chem. Res., 2014, 47, 864.

20 P. Pérez-Galán, N. Delpont, E. Herrero-Gómez, F. Maseras and A. M. Echavarren, Chem. - Eur. J., 2010, 16, 5324.

21 (a) D. W. Allen, L. A. March and I. W. Nowell, J. Chem. Soc., Dalton Trans., 1984, 483; (b) D. W. Allen and B. F. Taylor, J. Chem. Soc., Dalton Trans., 1982, 51; (c) A. Muller, S. Otto and A. Roodt, Dalton Trans., 2008, 650; (d) M. R. Axet, M. Barbazanges, M. Augé, C. Desmarets, J. Moussa, C. Ollivier, C. Aubert, L. Fensterbank, V. Gandon, M. Malacria, L.-M. Chamoreau and H. Amouri, Organometallics, 2010, 29, 6636.

22 C. Glidewell and E. J. Leslie, J. Chem. Soc., Dalton Trans., 1977, 527.

23 (a) A. Bayler, A. Bauer and H. Schmidbaur, Chem. Ber., 1997, 130, 115; (b) A. Hamel, N. W. Mitzel and H. Schmidbaur, J. Am. Chem. Soc., 2001, 123, 5106; (c) Y. Zhu, C. S. Day, L. Zhang, K. J. Hauser and A. C. Jones, Chem. - Eur. J., 2013, 19, 12264; (d) A. Homs, I. Escofet and A. M. Echavarren, Org. Lett., 2013, 15, 5782; (e) Z. Lu, J. Han, G. B. Hammond and B. Xu, Org. Lett., 2015, 17, 4534.

24 F. Schröder, C. Tugny, E. Salanouve, H. Clavier, L. Giordano, D. Moraleda, Y. Gimbert, V. Mouriès-Mansuy, J.-P. Goddard and L. Fensterbank, Organometallics, 2014, 33, 4051.

25 (a) C. Nieto-Oberhuber, S. López and A. M. Echavarren, J. Am. Chem. Soc., 2005, 127, 6178; (b) C. Bartolomé, Z. Ramiro, D. GarcíaCuadrado, P. Pérez-Galán, M. Raducan, C. Bour, A. M. Echavarren and P. Espinet, Organometallics, 2010, 29, 951; (c) M. Raducan, M. Moreno, C. Bour and A. M. Echavarren, Chem. Commun., 2012, 48, 52; (d) S. Ito, S. Kusano, N. Morita, K. Mikami and M. Yoshifuji, J. Organomet. Chem., 2010, 695, 291; (e) M. Raducan, C. RodríguezEscrich, X. C. Cambeiro, E. C. Escudero-Adán, M. A. Pericás and A. M. Echavarren, Chem. Commun., 2011, 47, 4893.

26 C. Nieto-Oberhuber, S. López and A. M. Echavarren, J. Am. Chem. Soc., 2005, 127, 6178.

27 M. J. Johansson, D. J. Gorin, S. T. Staben and F. D. Toste, J. Am. Chem. Soc., 2005, 127, 18002.

28 (a) P. Mauleón, R. M. Zeldin, A. Z. González and D. Toste, J. Am. Chem. Soc., 2009, 131, 6348; (b) I. Alonso, B. Trillo, F. López, S. Montserrat, G. Ujaque, L. Castedo, A. Lledós and J. L. Mascarenas, J. Am. Chem. Soc., 2009, 131, 13020; (c) D. Benitez, E. Tkatchouk, A. Z. Gonzalez, W. A. Goddard III and F. D. Toste, Org. Lett., 2009, 11, 4798; (d) M. Alcarazo, T. Stork, A. Anoop, W. Thiel and A. Fürstner, Angew. Chem., Int. Ed., 2010, 49, 2542.

29 (a) A. Marinetti, H. Jullien and A. Voituriez, Chem. Soc. Rev., 2012, 41, 4884; (b) A. Pradal, P. Y. Toullec and V. Michelet, Synthesis, 2011, 1150; (c) F. Lopez and J. L. Mascarenas, Beilstein J. Org. Chem., 2013, 9, 2250; (d) W. Zi and F. D. Toste, Chem. Soc. Rev., 2016, DOI: $10.1039 / \cos 00929 \mathrm{~d}$.

30 (a) K. Schlögl and M. Widhalm, Chem. Ber., 1982, 115, 3042; (b) L. Norel, M. Rudolph, N. Vanthuyne, J. A. G. Williams, C. Lescop, C. Roussel, J. Autschbach, J. Crassous and R. Reau, Angew. Chem., Int. Ed., 2010, 49, 99; (c) V. A. Soloshonok, T. Ono, H. Ueki, N. Vanthuyne, T. S. Balaban, J. Burck, H. Fliegl, W. Klopper, J.-V. Naubron, T. T. T. Bui, A. F. Drake and C. Roussel, J. Am. Chem. Soc., 2010, 132, 10477; (d) T. Tozawa, Y. Komoda, J. Ohnishi, Y. Matsuda, J. Taniuchi, C. Nakanishi and K. Okamoto, US pat., 5298642, 1994; (e) C. Shen, E. Anger, M. Srebro, N. Vanthuyne, L. Toupet, C. Roussel, J. Autschbach, R. Reau and J. Crassous, Chem. - Eur. J., 2013, 19, 16722.

31 (a) H. Liu, D. Leow, K.-W. Huang and C.-H. Tan, J. Am. Chem. Soc., 2009, 131, 7212; (b) S. Knoppe, I. Dolamic, A. Dass and T. Bürgi, Angew. Chem., Int. Ed., 2012, 51, 7589.

32 CCDC $1448370(($ aR $)-(+)-7) \& 1448371(($ aS $)-(-)-7)$. 